\title{
Bioactive Compounds Isolated from Neglected Predatory Marine Gastropods
}

\author{
Ashlin H. Turner ${ }^{(D)}$, David J. Craik, Quentin Kaas * and Christina I. Schroeder* \\ Institute for Molecular Bioscience, The University of Queensland, Brisbane, 4072, Qld, Australia; \\ ashlin.turner@imb.uq.edu.au (A.H.T.); d.craik@imb.uq.edu.au (D.J.C.) \\ * Correspondence: q.kaas@imb.uq.edu.au (Q.K.); c.schroeder@imb.uq.edu.au (C.I.S.); \\ Tel: +61-7-3346-2021 (Q.K. \& C.I.S.)
}

Received: 7 February 2018; Accepted: 29 March 2018; Published: 5 April 2018

\begin{abstract}
A diverse range of predatory marine gastropods produce toxins, yet most of these molecules remain uncharacterized. Conus species have received the most attention from researchers, leading to several conopeptides reaching clinical trials. This review aims to summarize what is known about bioactive compounds isolated from species of neglected marine gastropods, especially in the Turridae, Terebridae, Babyloniidae, Muricidae, Buccinidae, Colubrariidae, Nassariidae, Cassidae, and Ranellidae families. Multiple species have been reported to contain bioactive compounds with potential toxic activity, but most of these compounds have not been characterized or even clearly identified. The bioactive properties and potential applications of echotoxins and related porins from the Ranellidae family are discussed in more detail. Finally, the review concludes with a call for research on understudied species.
\end{abstract}

Keywords: toxins; marine gastropods; salivary glands; peptides; Ranellidae; echotoxins

\section{Introduction}

Predatory marine gastropods are at a distinct disadvantage when attempting to catch larger, faster, or more agile prey; but they have evolved potent venoms to subdue their prey to compensate for their small size and slow pace [1,2]. The most studied marine gastropod venoms are those of the Conidae, also called Conus species and commonly named cone snails, which use a harpoon-like radula tooth to deliver potent neurotoxins. Different Conus species feed on different prey, ranging from small fish to worms and even other gastropods [3-5]. The venom of each of the $>700$ cone snail species comprises a complex mixture of hundreds to thousands of peptides, called conopeptides; most of them target specific ion channels and transporter subtypes of the nervous system [1,2,6]. Cone snail venoms display large variability between species and even between individuals of the same species, and the total pool of cone snail peptides is estimated to be in the hundreds of thousands [7-9]. For more than 40 years, cone snail venoms have been mined for drug-lead compounds, the most well-known being conopeptide MVIIA (ziconotide), which is used clinically for treating intractable pain [10]. Several other conopeptides have entered clinical trials with varying levels of success [1].

Whereas Conus species have been in the spotlight of drug discovery, several other marine gastropod species are also potential sources of pharmaceutically attractive bioactive compounds. For example, while true venom glands are limited to (but not ubiquitous in) the superfamily Conoidea [11], some species from the Tonnoidea superfamily have indeed demonstrated the ability of their accessory salivary glands to function as 'venom' glands [3,12]. Most species of predatory gastropods in Tonnoidea have a large pair of salivary glands that are differentiated into anterior and posterior lobes, and are responsible for producing sulfuric acid ( $\mathrm{pH}$ 2) [13,14]. 
This review aims to summarize what is known from neglected families of carnivorous gastropods (Figure 1, Table 1); starting with a broader view of known poisonous marine gastropods, and then focusing on the understudied Ranellidae family. It provides an update to the Modica and Holford review published in 2010 [15], similarly focusing on bioactive substances found in Neogastropoda, but also expanding the scope to include other interesting but understudied gastropod families. All cited taxonomy follows the World Register of Marine Species (WoRMs).

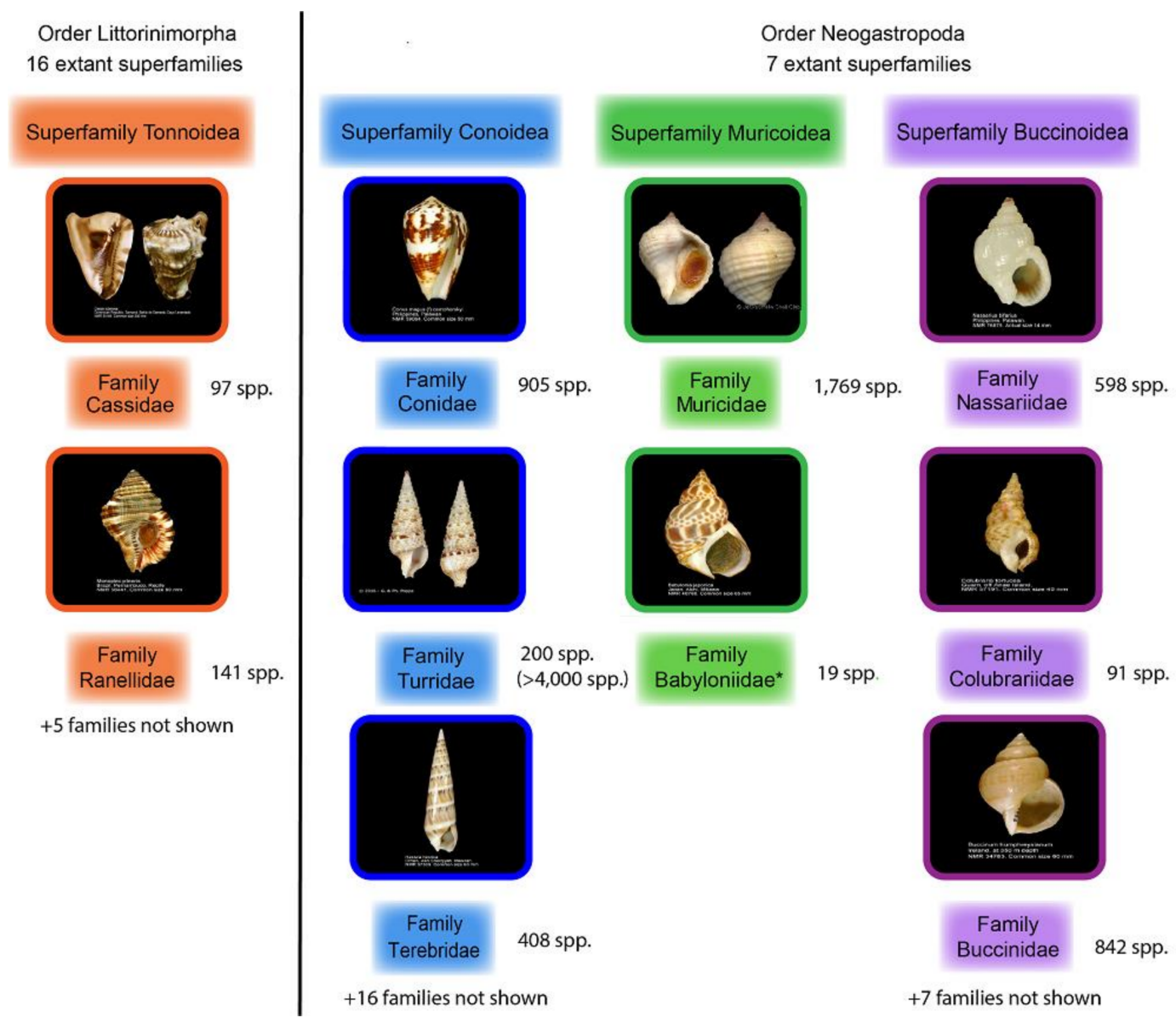

Figure 1. Families from Subclass Caenogastropoda that are covered in this review. Family and species numbers are current as listed from the WoRMs database and represent confirmed species within that family, whereas the species numbers in brackets represent an estimate of the total diversity from published literature [16]. Photographs are from the WoRMs database and provided under the Creative Commons License [17]. * The classification of the family Babyloniidae is currently under review by the ICZN [17].

Table 1. Summary of species discussed in this article and their reported bioactive components or physiological effects.

\begin{tabular}{lll}
\hline Family & Species & Toxin \\
\hline Conidae & Various & Conopeptides, CRiSPs, metallopreases \\
Terebridae & Hastula hectica & Teretoxins \\
& Terebra subulata & Teretoxins \\
& Terebra argus & Teretoxins \\
& Terebra guttata & Teretoxins \\
& Cinguloterebra anilis & Teretoxins, cytolytic proteins/actinoporins \\
& Terebra consobrina & Teretoxins, cytolytic proteins/actinoporins \\
Turridae & Lophiotoma olangoensis & Turritoxins \\
\hline
\end{tabular}


Table 1. Cont.

\begin{tabular}{|c|c|c|}
\hline Family & Species & Toxin \\
\hline & Polystira albida & Turritoxins \\
\hline & Gemmula periscelida & Turritoxins \\
\hline \multirow[t]{9}{*}{ Buccinidae } & Buccinum leucostoma & Tetramine, cholines/murexines \\
\hline & Buccinum schantaricum & Tetramine, unknown nervous system depressant? Stimulant? \\
\hline & Buccinum undatum & Cholines/murexines \\
\hline & Neptunea antiqua & Tetramine, unknown nervous system depressant \\
\hline & Neptunea arthritica & Tetramine \\
\hline & Neptunea intersculpta & Tetramine \\
\hline & Neptunea. kuroshiro & Tetramine \\
\hline & Neptunea lyrata & Tetramine \\
\hline & Cantharus tranquebaricus & Antimicrobial, cytolytic activity? \\
\hline Babylonidae & Babylonia japonica & Surugatoxin \\
\hline \multirow{6}{*}{ Muricidae } & Hexaplex trunculus & Choline esters/murexines, brominated indoles \\
\hline & Ocenebra erinaceus & Choline esters/murexines, brominated indoles \\
\hline & Bolinus brandaris & Choline esters/murexines, brominated indoles \\
\hline & Nucella lapillus & $\begin{array}{l}\text { CRiSPs? Choline esters/murexines, brominated indoles, } \\
\text { unknown nervous system depressant? Stimulant? }\end{array}$ \\
\hline & Stramonita haemastoma & Unknown nervous system depressant? Stimulant? \\
\hline & Acanthinucella spirata & Cholines/murexines, unknown nervous system depressant \\
\hline \multirow{3}{*}{ Cassidae } & Cassis tuberosa & Unknown nervous system depressant \\
\hline & Cassis madagascarensis & Unknown nervous system depressant \\
\hline & Cassis flammea & Unknown nervous system depressant \\
\hline Colubraridae & Cumia reticulata & Metalloproteases, cytolytic proteins/actinoporins \\
\hline \multirow{5}{*}{ Ranellidae } & Charonia lampas & Cytolytic proteins/actinoporins, unknown neurostimulant \\
\hline & Charonia tritonis & CRiSPs, metalloproteases, echotoxins \\
\hline & Fusitriton oregonensis & Tetramine \\
\hline & Monoplex intermedius & Unknown neurostimulant \\
\hline & Monoplex parthenopeus echo & Echotoxins \\
\hline
\end{tabular}

\section{Bioactive Compounds Isolated from Diverse Predatory Gastropods}

\subsection{Terebrids-Auger Snails}

Besides Conus, a subset of the closely related family Terebridae (terebrids) also possesses a specialized radula, used as a spear or harpoon to deliver potent neurotoxins. These $\sim 300$ known species fall into three feeding types [18]: type I species have salivary glands, an eversible labile tube, short buccal tube, and lack venom apparatus; type II species, the most similar to Conus, have true venom glands and a delivery apparatus in the form of a specialized radula; and type III lack a venom apparatus, but have an accessory proboscis that other terebrids lack [11,19]. Several type II species have a venom that exhibits similarities to conopeptides. These members of Terebridae produce small peptides with multiple disulfide linkages, named "teretoxins" [20,21]. Although bearing superficial similarities to conopeptides, there are several differences between teretoxins and conopeptides; most notably they have distinct sequences, degree of post-translational modifications and some of their cysteine frameworks were not found in conopeptides [18].

From Terebra subulata, three teretoxins (Agx-S6a, Agx-S7a, AgxS11a) were purified and demonstrated no posttranslational modifications besides the formation of disulfide bonds, whereas conopeptides are typically heavily posttranslationally modified [22]. These toxins were highly divergent from conopeptides but display a similar cysteine framework, as illustrated in Figure 2. In a later study, eight teretoxins were purified from Hastula hectica, and these toxins also displayed no posttranslational modifications [18]. Interestingly, several enzymes involved in posttranslational modifications of peptides were discovered in the transcriptome of Terebra venom glands, suggesting that teretoxins can display a range of posttranslational modifications. Identified enzymes in Cinguloterebra anilis (previously known as Triplostephanus anilis) and Terebra subulata include $\gamma$-glutamyl carboxylase, peptidyl-glycine $\alpha$-amidating monooxygenase, prolyl-4-hydroxylase, 
tyrosyl-sulfotransferase, and glutaminyl-peptide cyclotransferase [21]. Especially, the $\gamma$-glutamyl carboxylase enzyme catalyzes the $\gamma$-carboxylation of Glu into Gla, which is a frequent modification of conopeptides [23]. Such modification could not be detected in the venom of Hastula hectica using Gla-specific monoclonal antibodies, supporting that teretoxins are generally less post-translationally modified than conopeptides [18].

A



B

Tan4.1 (Triplostephanus anilis) AsXIVA (Conus austini)

C

Tv1

(Terebra variegata)
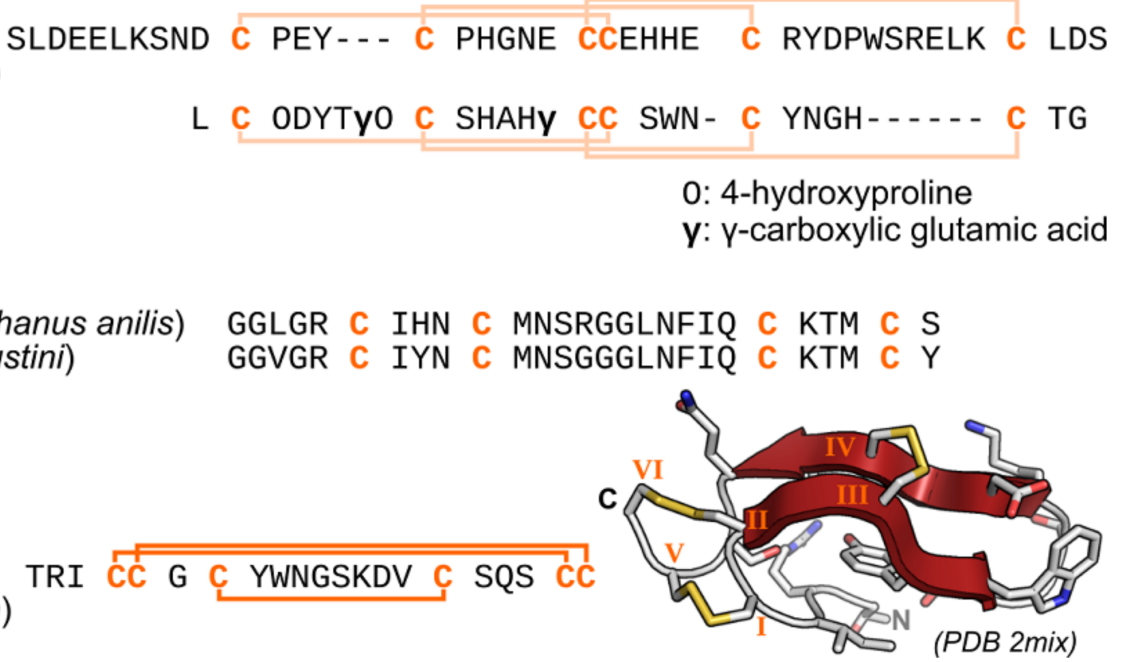

Figure 2. Sequence and structure of selected teretoxins. (A) Comparison of the mature toxins of teretoxin Agx-S6a to the conopeptide Gla(3)-TxVI [24], which is the closest conopeptide to Agx-S6a in the ConoServer database [23]. (B) Comparison of the predicted mature sequence of teretoxin Tan4.1 to the sequence of conopeptide AsXIVA [25], which share 85\% similarity. (C) Sequence and structure of teretoxin Tv1 solved by nuclear magnetic resonance solution [26]. The species from which each peptide originates is indicated in parentheses. The Cys residues are in orange. Disulfide connectivities predicted by homology are indicated by light orange lines and experimentally verified connectivities are represented as dark orange lines. The $\mathrm{N}$ and $\mathrm{C}$ termini are indicated on the structure of Tv1 and the $\beta$-sheet is colored in red. The Cys residues are numbered using Roman numerals on the three-dimensional structure.

The largest study of terebrid venom came from a transcriptomics study of Cinguloterebra anilis and Terebra subulata in which 139 putative teretoxins were identified [21]. These toxins display highly variable sequences and a high diversity of cysteine frameworks, suggesting a range of neural targets. The organization of the teretoxin transcripts was remarkably similar to that of cone snail toxins, with a signal peptide and a mature peptide region, which is excised from a precursor region. Conopeptides are classified into gene superfamilies according to the sequence similarity of their signal peptides, and a similar classification was attempted for this set of terebrid transcripts, leading to the identification of 14 gene superfamilies [21]. The consensus signal peptide sequences defining these superfamilies were generally different from those of the conopeptide gene superfamilies with the exception of the TM terebrid gene superfamily, which displayed $80 \%$ sequence identity in its signal sequence to the $\mathrm{H}$ conopeptide gene superfamily. In this study, twelve cysteine frameworks were discovered, ten of which were already described for conopeptides, but two were novel cysteine frameworks [21]. All teretoxins predicted from these transcriptomic sequences had no sequence similarity with known conopeptides with the exception of one teretoxin, Tan14.1, which has marked similarity to conopeptide AsXIVa (Figure 2).

Cysteine frameworks are strongly associated with the three-dimensional conformation of disulfide-rich peptides and their function. Nevertheless, the cysteine framework classification does not consider the connectivity between Cys, which is difficult to determine, but only their pattern in the toxin primary sequence, and the cross-links created by disulfide bonds are a major determinant 
of the fold of small peptides. Therefore, teretoxins displaying novel cysteine frameworks [21] have a high probability of adopting novel folds, but even toxins displaying a framework identified in cone snail toxins could display a different disulfide connectivity and therefore different structure. This is exemplified with teretoxin Tv1 (Figure 2), which displays a conopeptide cysteine framework III but its disulfide connectivity is yet unseen in framework III conopeptides, resulting in a different fold from conopeptides [26]. It should be noted that three different connectivities of framework III conopeptides have been identified, demonstrating that this framework can lead a variety of folds [1].

Teretoxins appear to have similar biological effects on the nervous system to conopeptides. Indeed, a teretoxin isolated from Terebra guttata produced paralysis in polychaete worms [27] and injection of the venom from Terebra subulata and Hastula hectica in Caenorhabditis elegans elicited uncoordinated motions before paralysis $[18,22,28]$. Teretoxins from Terebra argus and Terebra consobrina primarily affected nicotinic acetylcholine receptors, but had no effect on voltage-gated potassium or sodium channels, as reported by Kendel [28]. It should be noted that venom extracts were used in these assays, and therefore Kendel speculates some low abundance toxins could still be targeting voltage-gated ion channels but would not have been noted in his experimental set-up [28]. Interestingly, Tv1 shares $85 \%$ sequence identity with conopeptide AsXVIA, which was postulated to target potassium channels [25].

Gorson et al. reported the identification of transcripts of putative pore-forming toxins identified from Cinguloterebra anilis and Terebra subulata [21]. These were named "tereporins" and determined to be closely related to conoporins from Conus geographus and Conus radiatus, as well as bearing similarities to actinoporins and echotoxins (discussed below) [21].

In summary, teretoxins have many similar features to conopeptides, but there are differences in cysteine frameworks and size [21,27]. Similar to Conus, analogues of conopressins and pore-forming toxins have also been found in Terebridae [21]. With approximately 300 different species of terebrids, and multiple new superfamilies of teretoxins identified from just a few species, there are a large number of novel teretoxins awaiting characterization and these toxins could display novel cysteine frameworks, three-dimensional structures, or biological activities [19,21].

\subsection{Turridae}

Turridae is a large (estimated $4000 \mathrm{spp}$.) family of small, predominately deep-sea dwelling species, that belong to the superfamily Conoidea and are therefore related to terebrids and cone snails $[16,21]$. Originally this large group was classified as a single family; but, more recently the taxonomy of this family has become hazy with multiple subfamilies proposed and rejected [29,30]. In addition, turrids make up most of the diversity in the Conoidea superfamily, making this family a fascinating starting point for the discovery of new bioactive compounds [20,31,32]. Turrids have a venom duct, but because of their small size, it is highly difficult to extract toxins, limiting the research carried out into these species. Despite these limitations, it is estimated that there are more than 10,000 different turritoxins [32]. From analysis of the DNA extracted from turrid Lophiotoma olangoensis, it was found this species has the capacity to produce peptides similar to the conopeptides of the I and P gene superfamilies [32]. However, the genes that encode "turritoxins" in Lophiotoma olangoensis have very little sequence similarity with those of Conus [32]. Only one gene superfamily in Lophiotoma olangoensis, which encodes a subset of turritoxins, has clear similarity to conopeptides, more specifically to I-superfamily conopeptides [32]. The size of the peptides is also different, with turritoxin peptides containing 80-110 amino acids, whereas most conopeptides are typically 10-30 amino acids in length [32]. A similar study of Gemmula speciosa discovered several conopeptide-like precursors [20]. Some turritoxins have been shown by Edman degradation to be post-translationally modified like conopeptides, with some proline and glutamate residues being modified into hydroxyprolines and $\gamma$-carboxyglutamic acid, respectively [20]. The amino acid sequence of toxins displaying the same cysteine frameworks were described as highly divergent, suggesting turritoxins potentially represent a large pool of diverse bioactive compounds [20]. Nevertheless, the analysis of the venom of other turrid species produced contrasting results, with the venoms of Polystira albida and Gemmula periscelida lacking cysteine rich peptides, as determined by MALDI and MS [31]. It was 
found that the prevalent peptides isolated from each species were homologous and were composed of $\alpha$-helical regions [31]. The afore-mentioned study only isolated one major component from each species of turrid [31]. These peptides were found to contain a high number of tyrosine, arginine, and especially methionine residues, which are probably responsible for the formation of the $\alpha$-helices (Figure 3) [31]. It is likely these peptides form coiled-coil motifs, which could function as stabilizing agents in the absence of disulfide bonds [31]. These peptides, named PaIAa and GpIAa constitute a novel class, and are not similar to conopeptides or to other turritoxins; this type of peptide is structurally characterized by the methionine regions, "methionine zipper" [31].

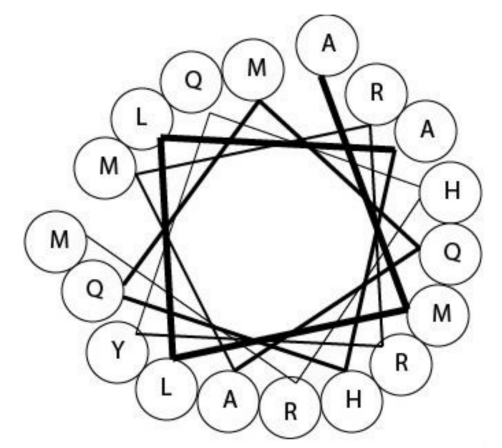

Figure 3. Helical wheel representation of Polystira albida turritoxin (PaIAa) residues 33-50, which form one of two predicted $\alpha$-helixes.

The turritoxin ubi3a, isolated from Lophiotoma bisaya, produces tremors in mice on intracranial injection [33]. This turritoxin displays a cysteine pattern similar to the conopeptide cysteine framework III [33]. Despite this similarity, ubi3a has a disulfide connectivity that has not yet been described in conopeptides [33]. It has excitatory activity in mouse dorsal root ganglion neurons; the specific target receptor was not identified, but activity on the nicotinic acetylcholine receptors was ruled out [33].

\subsection{Buccinidae-True Whelks}

One of the first reports of a neurologically active compound found in marine gastropod saliva was from a member of the Buccinidae family, Neptunea antiqua, when it was determined that the effects of the salivary gland extract were identical to the effects of neurine [34]. In multiple reports, it was found that diluted and buffered ( $\mathrm{pH} 7$ ) saliva was just as effective as the native acidic extract at paralyzing various species of gastropods, polychaetes, and urchins $[34,35]$. It was later reported that the saliva of some members of Buccinidae and Ranellidae families contains tetramethylammonium (or tetramine, Figure 4A), chemically similar to neurine, in concentrations high enough to cause food poisoning [36]. The marine gastropod species displaying high content of tetramine are Buccinum leucostoma, Neptunea antiqua, Neptunea arthritica, Neptunea intersculpta, Neptunea kuroshio and Neptunea lyrata, from the Buccinidae family, as well as Fusitriton oregonensis from the Ranellidae family (previously Argobuccinum oregonense) [37,38]. Other species in these families did not produce tetramine, therefore tetramine does not appear to be ubiquitous within Ranellidae or Buccinidae $[39,40]$.

Tetramine (Figure 4A) acts by blocking nicotinic acetylcholine receptors, but human food poisoning cases caused by ingesting these gastropods are fortunately not serious because this toxin is easily degraded or cleared [14,37]. Indeed, symptoms typically vanish within $24 \mathrm{~h}$ at most, with no long-term complications reported [41,42]. An extensive study by Anthoni et al. [39] reports that only tetramine is responsible for toxic secretions of Neptunea antiqua. However, unpublished observations by West and Bowman point to additional bioactive substances in the salivary secretion of this species, though the specifics of these findings were not reported [3]. A closely related species, Neptunea arthritica, produces histamine and choline derivatives, in addition to tetramine $[40,43]$. 
A brief description of the bioactive extracts of Cantharus tranquebaricus demonstrated toxicity to brine shrimp, hemolytic activity, and some antimicrobial activity against Vibrio cholerae and Proteus mirabilis [44]. These extracts also appeared to have some proteolytic and fibrinolytic activity [44]. While the work was promising, additional studies using alternative methods are needed to support this report.

Buccinum leucostoma and Buccinum undatum were found to have acrylylcholine (Figure 4B), a neuromuscular blocking agent, in the hypobranchial gland [45]. Buccinum spp. are active predators of multiple species and although the reason for which these species use the compound is as yet undefined, it could be important for prey capture [46]. The salivary gland extract of Buccinum schantaricum was determined to be lethal to mice by intravenous injection [37], as mice injected with Buccinum schantaricum venom $(0.01 \mathrm{~mL} / \mathrm{g}$ body weight $)$ exhibited convulsions and died within $5 \mathrm{~min}$ [37]. However, the extract lost its toxicity after heating to $80^{\circ} \mathrm{C}$ for $5 \mathrm{~min}$. Lethal activity was calculated in titer units and found to be only 4-8 [37], with titer being defined as the reciprocal of the highest dilution found to be lethal; for example, if a $1 / 10(10 \%)$ dilution is lethal the corresponding titer unit would be 10. Large titer (in the thousands, for example) corresponds to greater toxicity. Low concentrations of tetramine were found in Buccinum schantaricum, considered by Shiomi et al. to be insignificant [37], suggesting that other compounds in the venom are responsible for the bioactivity.

\subsection{Cassidae—Helmet Shells}

Cassis tuberosa mainly preys on sea urchins, with little regard for the urchin's protective spines or toxins. Interestingly, when threatened, Cassis tuberosa will "spit" a clear liquid, evidently using its saliva as defense against other predators [47]. When the saliva was used in an in vivo study of urchins, it was found the saliva decreased the response of the urchin to sensory stimuli of all kinds, including light and touch [47]. Recovery was evidently complete, even after loss of all response to stimuli, except at the highest concentrations of saliva [47]. The unidentified compound was effective to some degree even at 400 ppm, with similar toxicity reported in two other species of Cassis: Cassis madagascariensis, and Cassis flammea [47].

\subsection{Colubrariidae-Vampire Snail}

The venom of Cumia reticulata (previously reported as Colubraria reticulata) was recently characterized using a RNA sequencing approach [48]. Cumia reticulata has a different feeding mechanism to other predatory gastropods mentioned previously; it feeds on the blood of fish that are resting nearby, leading to its common name, Vampire Snail. The venom is proposed to contain anesthetic peptide compounds, similar to the anemone potassium channel blocker ShK toxin. In addition, transcripts coding for putative inhibitors of primary hemostasis (ectonucleotide pyrophosphatase family), astacin metalloproteases, vasopressive proteins (angiotensive converting enzyme), and cytolytic porins were found [48]. The putative cytolytic porins display similarities to echotoxins, which are discussed in detail below [48]. Fascinatingly from an evolutionary perspective, a transcript coding for a peptide with a high similarity to some turripeptides was also discovered [48]. This study highlights the high diversity of proteinaceous components of predatory gastropod venoms.

\subsection{Muricidae—Rock Snails}

Muricids have been used in traditional medicine over centuries for treatment of various medical disorders [49]. This family is most famous for the production of Tyrian purple, brominated indoles and their derivatives (see Figure $4 \mathrm{D}-\mathrm{F}$ ), which are traditionally used as a dye and produced in the hypobranchial gland of the gastropod. The indole compounds and their variants are relatively well-documented and investigated as potential anti-tumor and antibiotic agents, as reviewed by Bekendorff et al. [50-53]. Toxic choline esters have also been isolated from this family, found in the hypobranchial gland as a salt of brominated indole precursors [54]. Two substances, urocanycholine (murexine) (Figure 4H) and senecioylcholine (Figure 4G), have been isolated from the family Muricidae and have neuromuscular blocking properties through inhibition 
of nicotinic acetylcholine receptors [35,55]. Urocanycholine was isolated from Hexaplex trunculus, Ocenebra erinaceus, and Bolinus brandaris [45]. This is significant as choline compounds are neuromuscular inhibitors, found in other families, and are chemically related to tetramine $[34,35,45]$. In fact, over 50 species within the superfamily Muricoidea contain murexine or senecioylcholine (see Figure 4G,H) or both within the hypobranchial gland [55].

The salivary secretion of Nucella lapillus contains high levels of serotonin (an indole compound, see Figure 4I) and unidentified inhibitors of neural voltage-gated calcium channels [3,14]. The extracts from Nucella lapillus demonstrated effects characteristic of urocanycholine (see Figure $4 \mathrm{H}$ ), and the active compound was later determined to be senecioylcholine $[55,56]$. However, there are also indications of another unidentified compound affecting nicotinic acetylcholine receptors [56]. It was found that this species secretes a glycoprotein that has several disulfide bonds, similar to many known toxins such as conopeptides, and might also be responsible for some of the bioactivity of the gland secretion [56,57]. Nucella lapillus has accessory salivary glands, in addition to the main salivary glands and it was proposed by West et al. [3] that these accessory salivary glands function as venom glands, being anatomically similar to cone snail venom glands. This proposal was not generally adopted, and these accessory salivary glands have remained "accessory" despite their important role in feeding. They are occasionally referred to as anterior salivary glands $[3,14,58]$.

The extracts from Acanthinucella spirata salivary glands, which mainly preys on mussels, was found to induce flaccid paralysis in mussel tissues [59]. Carboxylic esters, as well as acetylcholine and butylcholine, were discovered in the salivary glands [59]. It was speculated that the carboxylic ester, acting on the same receptors as acetylcholine, is the paralytic component of the salivary glands [59]. In addition, proteolytic components were reported in Chicoreus virgineus also from the Murex family, but these were not further investigated [46].

The salivary gland extract from Stramonita haemastoma (formerly known as Thais haemastoma) is toxic to mice with $\mathrm{LD}_{50}$ of $43 \mathrm{mg} / \mathrm{kg}$ [60]. In various toxicity studies, the salivary gland extract appeared to act as a depressant on the central nervous system, causing vasodilation, hypotension, and bradycardia in anaesthetized cats [60]. However, an electrocardiogram recording revealed that this salivary extract was not damaging to the heart [60]. In isolated vertebrate ileum and duodenum, application of the salivary extract caused rapid contractions, which were not blocked by atropine, and it was concluded that this extract contains a toxin that acts by direct stimulation of smooth muscle fibers [60]. A previous report had demonstrated high concentrations of choline esters and senecioylcholine in the tissues of Stramonita haemastoma [55]. This may be responsible for the effects observed from the salivary gland extract of this species. However, if there is another toxic component in the salivary glands Stramonita haemastoma, it has not been characterized.
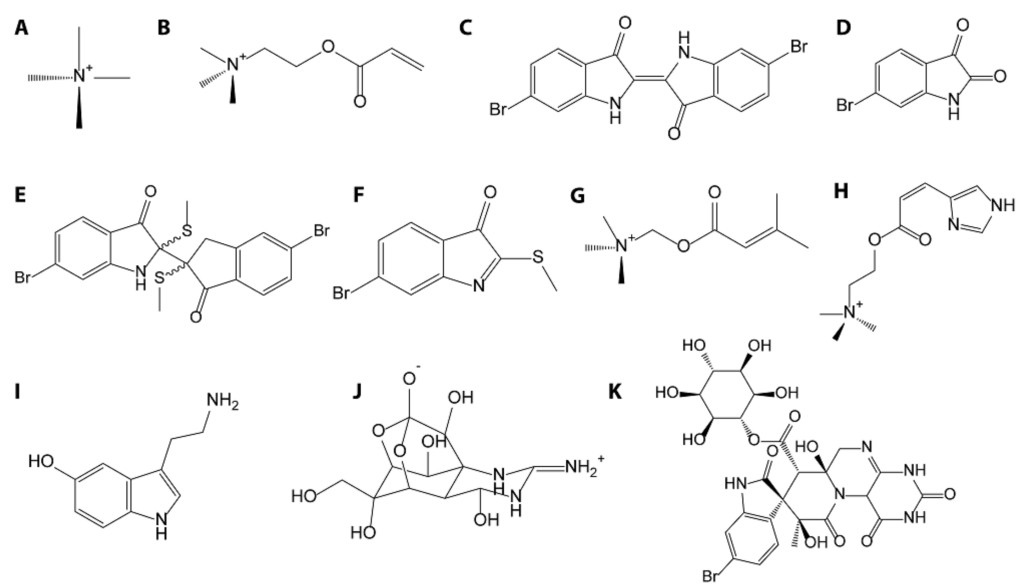

Figure 4. Small molecule compounds discussed in this review. (A) Tetramine, (B) acrylylcholine, (C) Tyrian purple, (D) 6-bromoisatin, (E) tyriverdin, (F) tyrindoleninone, (G) senecioylcholine, (H) urocanycholine (murexine), (I) serotonin (J) tetrodotoxin, and (K) surugatoxin. 


\subsection{Family Ranellidae}

The family Ranellidae has been investigated only minimally. Here we will summarize what is known about Ranellidae, starting with the better-known species and then focusing on the genus Monoplex.

\subsubsection{Genus Charonia}

Charonia lampas extracts cause instant paralysis of its main prey, the starfish Patiriella regularis by injection [45]. Charonia lampas toxins were unaltered by raising the temperature to $80^{\circ} \mathrm{C}$ and were lethal to mice at 1 unit of titer [36]. Mice injected with the extract showed increased activity, spontaneous convulsion and jumping, and died of respiratory arrest within two minutes with blood found in the mouth and nose [36]. The saliva of Charonia lampas does not seem to induce paralysis of its main prey, the sea stars, during feeding, suggesting that the saliva does not contain analgesic compound [61]. Morton [61] suggested that the saliva of Charonia lampas is not venomous, despite contradictory reports by Shiomi et al. [36] describing lethal effects of this species' salivary extract. Morton noted that the natural prey of Charonia lampas is the sea star Astropecten polyacanthus, which produces tetrodotoxin [61]. Charonia lampas has been reported to bioaccumulate tetrodotoxin, but tetrodotoxin cannot completely account for the activity observed in mice after injection [36,62]. Indeed, tetrodotoxin is a well-studied inhibitor of sodium ion channels, and associated symptoms in vertebrates include paralysis, abnormal heart rhythms, and respiratory arrest [62]. However, this toxin may not directly account for the increased activity or the blood found in the nose and mouth of the test animals.

The saliva of Charonia tritonis was first reported to paralyze its prey by Endean [45]. Recently, the composition of its saliva was analyzed from its salivary gland extract using a combined transcriptomics and proteomics approach [63]. It was found to contain cysteine-rich secretory proteins (CRiSPs), which were believed to have venom-like properties [63]. It was further speculated that these CRiSPs could be ion channel modulators, similar to their name-sake function in snake venom [63]. Metalloproteinases were also found in this study, and these proteins were also found in the venoms of cone snails, spiders, scorpions and platypus, which also use peptide toxins for defense $[64,65]$. In snake venom, metalloproteinases are responsible for breaking up tissue membranes and the extracellular matrix, which leads to hemorrhage $[66,67]$. In Charonia tritonis, the authors suggest these metalloproteinases may have a defensive function and call for further research into this area [63]. In a further study focusing on neuropeptides encoded by Charonia tritonis cerebral ganglion, authors found a transcript encoding a peptide similar to conopressins, which are expressed by cone snails Conus geographus and Conus striatus [68,69]. Conopressins have similar sequences to vasopressin and likely have neuroregulatory functions affecting multiple behaviors [68,70].

\subsubsection{Genus Monoplex}

Monoplex species are active predators of other invertebrates, mostly other gastropods, sponges, or bivalves. To subdue their prey, bioactive secretions are produced from the paired salivary glands (Figure 5). These glands are segmented into anterior and posterior, which have different functions. It is believed that the different sections of the salivary glands secrete different proteins and acid $[13,37,58,71]$. It was also proposed that a chelating agent could be secreted together with the acid to assist in breaking down the shell of prey species [38,58]. Monoplex intermedius produces a toxin in its salivary gland that stimulates vertebrate and invertebrate nicotinic acetylcholine receptors in vitro [72]. The action of this toxin could be blocked by (+)-tubocurarine but not by atropine [72], suggesting that this toxin acts on nicotinic receptors but not on muscarinic cholinergic receptors. The same work determined similar activity from the salivary glands of Monoplex gemmatus, Gutturnium muricinum and Monoplex nicobaricus [72]. Although its physiological effects imitate acetylcholine, the nature of this toxin was not determined [72]. 
A

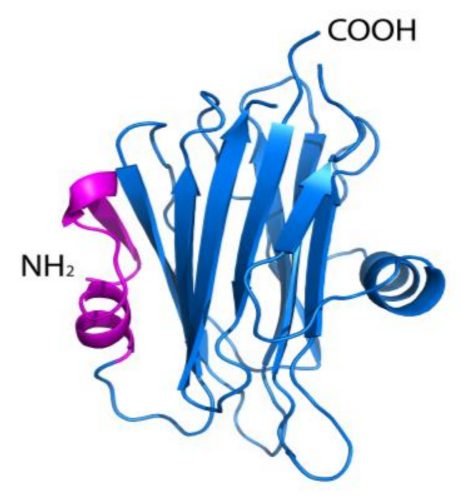

B

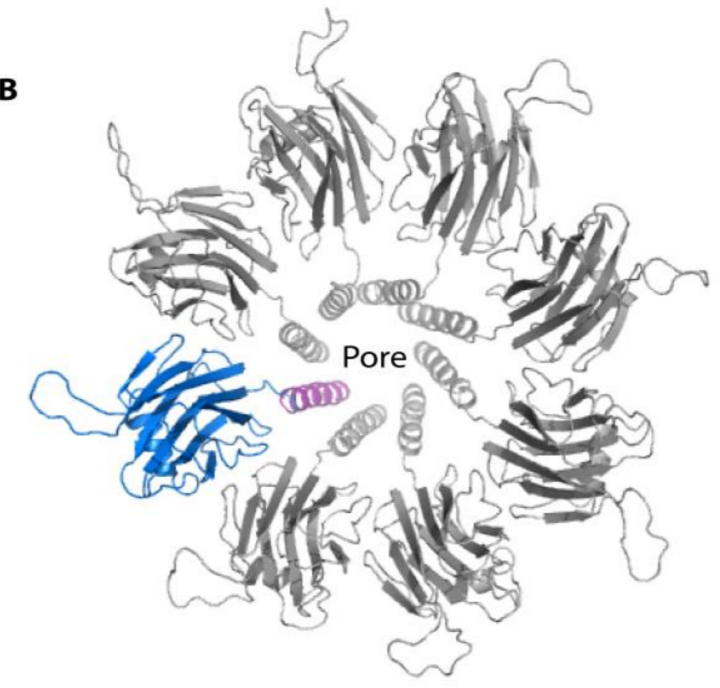

C

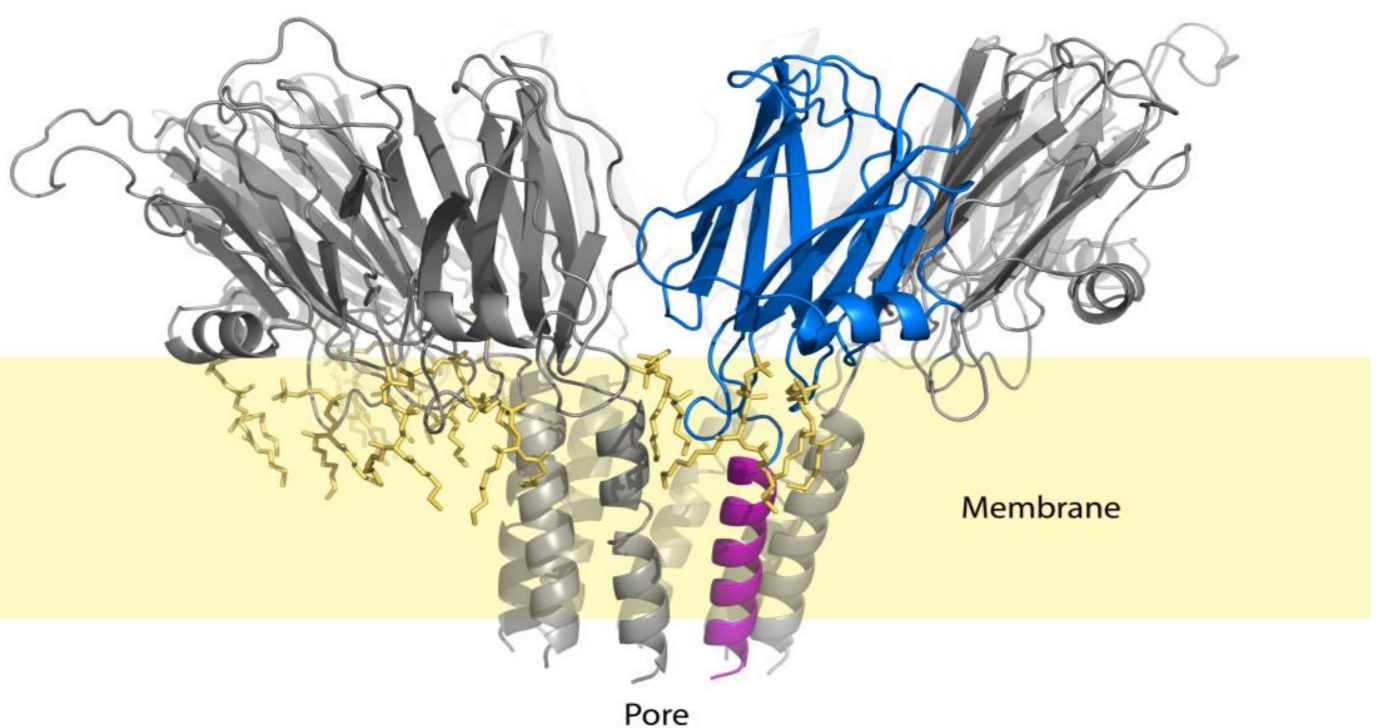

Figure 5. Putative three-dimensional structure of echotoxin 2 in monomeric (solution) and octameric (membrane-bound) forms. The structure was obtained by homology modeling using the crystallographic structure of fragaceatoxin C and generated using PyMol [73]. (A) Molecular model of monomeric, inactive echotoxin 2 (B) View from the extracellular side of the molecular model of echotoxin 2 in an octameric form (C) Side view of the molecular model of the octameric of echotoxin 2 embedded in a lipid bilayer (yellow). One of the monomer in each panel was represented in blue and its $\mathrm{N}$-terminal active region shown in pink. This region change conformation depending if the monomer is in solution $(\mathbf{A})$ or embedded in the membrane $(\mathbf{B}, \mathbf{C})$. The shaded region in $(\mathbf{C})$ represent the approximate position of the membrane.

A fine structure analysis of cellular morphology in Monoplex intermedius revealed that the salivary glands are arranged into tubules (Figure 6) [58]. At the end of each tubule the cells do not appear to express distinctive traits, but more distal to the end of the tubule the cells secrete a light, heterogeneous product, likely made up of diverse proteinaceous components [58]. Continuing distally down the tubule, cell morphology changes again; cells becoming larger with more large vacuoles [58]. These vacuoles contain an acidic solution and the plasma membrane was found to have deep folds [58]. Researchers hypothesized that the undifferentiated cells at the ends of the tubules are the youngest, which later move down the tubule and specialize into protein secretion, finally becoming acid-secreting (Figure 5) [58]. 


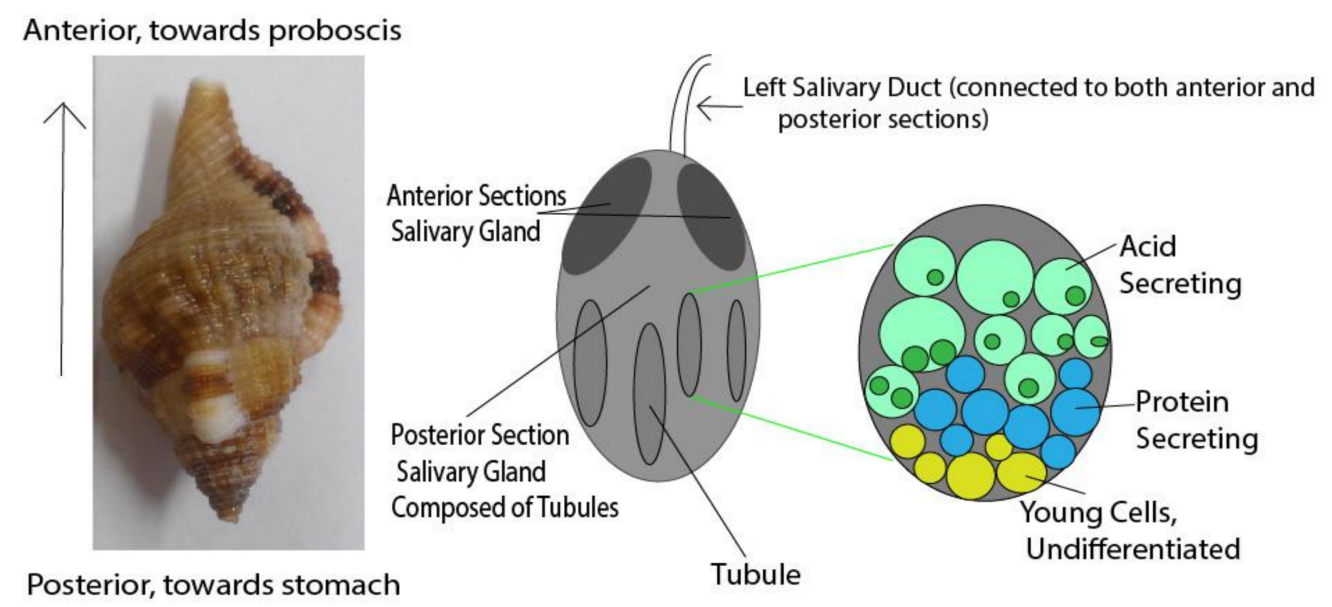

Figure 6. Diagram of the left salivary gland of Cymatium, showing the spatial differentiation within the blind tubules of the posterior salivary gland as described by Andrews et al. [58].

Echotoxins are $25 \mathrm{kDa}$ proteins isolated from the salivary gland of Monoplex parthenopeus echo, rich in glycine and alanine, and strongly inhibited by gangliosides [37]. Echotoxins were also found in the saliva of Charonia tritonis mentioned earlier in this review, which is the main predator of crown-of-thorns sea stars and is in the same family as Monoplex parthenopeus echo [63]. The main cause of death in mice injected with echotoxin was hemolysis, in contrast to the majority of other species discussed in this review with neurotoxic bioactivity [37]. The extract of Monoplex parthenopeus echo salivary glands were highly toxic with an $\mathrm{LD}_{50}$ of $82 \mu \mathrm{g} / \mathrm{kg}$ when injected intravenously into mice [37]. Assuming the effects on humans are comparable to those on mice, the equivalent is an estimated $6.4 \mathrm{mg}=\mathrm{LD}_{50}$ for $75 \mathrm{~kg}$ human. Echotoxins have similar biological activity to actinoporins, which are pore-forming hemolytic proteins isolated from Actiniidae and Stichodactylidae sea anemones $[71,74]$. Echotoxins also have similar size, basicity and N-terminal $\alpha$-helix and aromatic "patch" to actinoporins [71]. The three-dimensional structure of echotoxins has not yet been experimentally determined, but with the knowledge of its primary structure and homology with actinoporins, its structure may be similar to known actinoporins (Figure 5) [71].

Actinoporins and echotoxins have similar sequences, suggesting that they have similar activity, despite echotoxins lacking the arginine-glycine-aspartic acid (RGD) motif displayed by actinoporins (Figure 7) [71]. The RGD motif binds to integrin, which is a membrane protein, and this interaction possibly helps actinoporin to increase its local concentration at proximity of the targeted membrane. It is worth noting that conoporins, which are 36\% identical to echotoxin 2 in sequence, have been identified in the venom of the cone snail Conus consors [75]. In addition, several other isoforms of conoporins with similar basicity to echotoxins have been reported in the venom of Conus consors and Conus geographus [76,77]. As mentioned previously, Cumia reticulata was reported to produce 62 different porins with similarities to echotoxin, which raises some interesting questions from the point of comparative biochemistry. It was surmised that the pore-forming toxins produced by this gastropod were necessary for permeating the blood vessels when feeding [48].

It has been proposed that the $\mathrm{N}$-terminal $\alpha$-helical region is essential for the biological activity of echotoxin 2 just as it is for actinoporins [71]. When actinoporins self-associate, eventually forming octamers, the $\mathrm{N}$-terminus of each actinoporin monomer undergoes a conformational change and inserts into the cell membrane to form a pore (Figure 5) [73,74]. The similarities between echotoxin and actinoporins are shown in that they both interact with lipid components of cellular membranes, but probably use different mechanisms to recognize those membranes. Whereas actinoporins bind to sphingomyelin, echotoxins bind preferentially to gangliosides [71]. Gangliosides, unlike sphingomyelin, have no choline phosphate group, a negative charge, and are arranged asymmetrically with their carbohydrate moiety displayed on the extracellular side of the membrane [65]. 


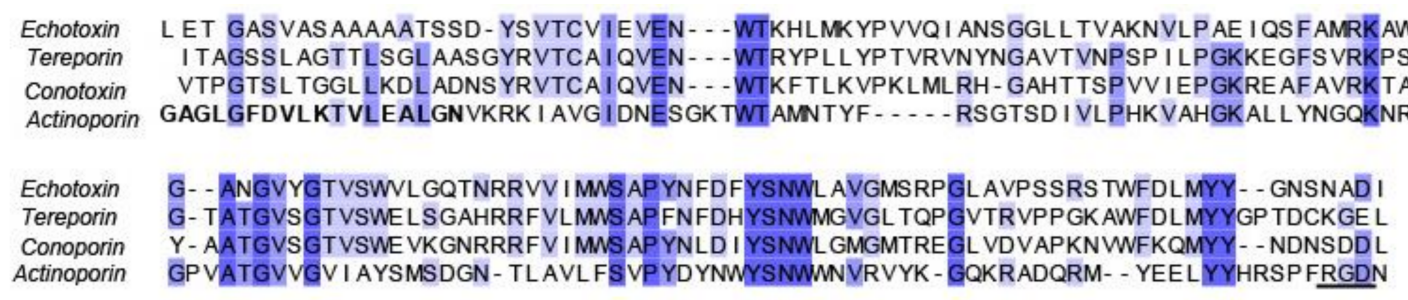

Echotoxin SFVRGEYYHSVDP I YFKNSEWE IE GSMNN I HKÄRVRATVKP I

Tereporin RYE RGEFYYT IDPVI YRDENFE I V GTMTNVHNAL I KVVIRPT

Conoporin TFE RKKFYKNLDTFL YSNKKFEAE GDMTNSHHAL VRVI FRPA

Actinoporin GWHSRGLGYGLKS -........-. R GFMNSSGHA I LE IHVTKA

Figure 7. Sequence homology of echotoxin isolated from Monoplex echo with an actinoporin from Actinia fragacea; as well a conoporin from Conus geographus and a partial sequence of a tereporin from Cinguloterebra anilis. The RGD motif, present in the actinoporins but not the echotoxins, conoporins, or tereporins, is underlined. The N-terminal active region of the actinoporin is shown in bold. All sequences were retrieved from UniProt (accession numbers in Table A1) and aligned using Muscle [64].

\subsection{Bioaccumulated Toxins-Selected Examples}

There is a wealth of literature on the bioaccumulation of toxins (especially tetrodotoxin, organotins, and heavy metals) by marine gastropods, but this subject will not be extensively covered in this review, which primarily focuses on compounds produced by predatory gastropods. For a sample of the vast available literature on bioaccumualtion of various toxins relevant to the species mentioned in this review the reader is referred to Chau et al. [62], Costa et al. [78], Borysko and Ross [79], Choi et al. [80], Coelho et al. [81], Hwang et al. [82], and Zou and Kong [83]. For example, species of the Nassarius family, also known as the dogwhelks and closely related to Buccinidae, bioaccumulate toxins $[83,84]$. These species are often used as indicators of pollution, owing to their scavenging lifestyle and efficiency in bioaccumulating toxins [76,77,80-82,85]. Recently, the taxonomy of Nassaridae was rewritten using genetic barcoding and nuclear genetic markers, resulting in a call for a reassessment of the traditional classification based on morphology [86]. The formidable and often confusing taxonomy of these species, as well as lack of public information on which species are bioaccumulating or potentially producing toxins, makes these species generally dangerous for human consumption $[76,77,80-83,85]$. This makes the continuing popularity of these various species for sale as food, especially in China and Taiwan, rather puzzling $[82,83]$. The sale of toxic Nassarids is illegal in China, however, further research is needed to identify exactly which species bioaccumulate or produce toxins and whether these toxins are seasonal or not [83]. This information would be essential to ensure food safety of the general population. Charonia lampas has also been reported to bioaccumulate tetrodotoxin (see Figure 4J), and is discussed in further detail in the section on family Ranellidae [36,62].

The Japanese Ivory snail (Babylonia japonica) contains surugatoxin (see Figure 4K), an anti-nicotinic and ganglionic blocking neurotoxin [34,35]. Although it was initially believed that surugatoxin was produced by the snail, later work proposed that microbial activity (Corynebacterium spp.) was responsible for producing the precursors of surugatoxin in the gut of the snail [87].

\section{Pharmaceutical and Biotechnological Applications}

\subsection{Venom-Derived Peptides}

The applications of venom-derived disulfide peptides are numerous due to their specificity to various ion channels and receptors [88]. The intense biological selection pressure that produces a venom cocktail has been described as numerous successive clinical trials, weeding out ineffective compounds until only the most potent remain [88]. The approval of Prialt in the European Union and United States, as mentioned above, set the precedent for peptides as pharmaceuticals [10]. 
However, treatment of pain is far from the only application of bioactive peptides isolated from marine animals. ShK, a highly effective inhibitor of $\mathrm{K}_{\mathrm{V}} 1.3$ channels isolated from the sea anemone Stichodactyla helianthus, has been investigated for the treatment of several autoimmune disorders such as multiple sclerosis [88]. Conantokin-G, isolated from Conus geographus, is an NMDA antagonist that was found to have neuroprotective effects by reducing NMDA excitotoxicity $[89,90]$. In rat models of stroke, this ion-channel inhibitor significantly improved neurological recovery after ischemic injury [90]. The applications of highly selective and potent peptides are extremely broad, and an attempt to list all the potential biomedical applications alone is far beyond the scope of this review. For a review of conotoxins and their activities, the reader is referred to Akondi et al. and Halai and Craik $[1,91]$. The examples above are only a small fraction of the available research on venom-derived peptides. Multiple other peptides with high affinities for other channels have been described from Turridae and Terebridae and more await discovery, promising to be as fruitful as conopeptides [20,21].

\subsection{Brominated Indoles-Muricidae}

Brominated indoles and their derivatives, as mentioned above, are produced by family Muricidae in the hypobranchial gland. These compounds are often found on the egg masses laid by members of this family and have been tested for antimicrobial and anticancer activity $[50,51,53,92]$. The compounds tyrindoleninone, tyriverdin, and 6-bromoisatin (see Figure 4) inhibited the growth of pathogens, both terrestrial and marine [92]. Tyrindoleninone and 6-bromoisatin, as well as other bromoisatin derivatives, were shown to inhibit multiple cancer cell lines, with minimal cytotoxicity to normal cells [51,52]. These compounds induce apoptosis in cancer cell lines and related indigo compounds have been patented for use in treatment of cancer [93-95]. In pre-clinical trials on mouse models of colorectal cancer, 6-bromoisatin induced apoptosis and prevented proliferation in cancer cells [93-95]. Other applications of these compounds and their relatives include use as anti-inflammatory agents [50,96-98]. In mouse model of acute lung inflammation, the hypobranchial gland extract from Dicathais orbita preserved lung tissue significantly better than the controls [98]. In fact, isatins and indole derivatives have been patented for treatment of inflammation and allergies $[50,99]$. Extensive research exists on the applications of brominated indoles, therefore the reader is referred to Benkendorff et al. for a further review of active components isolated from Muricidae [50].

\subsection{Murexine}

The use of murexine (see Figure $4 \mathrm{G}$ ) as a muscle relaxant was investigated in the clinic by Erspamer and Glasser [100] as it appears to act on nicotinic acetylcholine receptors to produce paralysis. The action of murexine was more powerful than suxamethonium, the most similar compound tested in this experiment. The effects of murexine were temporary, only lasting 3 to $6 \mathrm{~min}$ [100]. Erspamer and Glasser initially suggested that murexine be investigated for anesthetic use and investigated murexine and related compounds for application as muscle relaxants $[100,101]$. However, some of the side effects of murexine were not desirable and its use in the clinic was discontinued $[100,101]$.

\subsection{Echotoxins}

The potential applications of pore-forming proteins such as echotoxins includes uses in the medical and analytical fields [102]. The delivery of proteins, peptides, and oligonucleotides to cells is severely limited by their inability to permeate the cell membrane [103] and pore-forming toxins may provide a platform for drug delivery on a cellular level. This could open a new field for pharmaceutical nano-particle based treatments $[102,104]$. The ability of pore-forming toxins to deliver cargo directly to the cytoplasm has already been demonstrated using disarmed anthrax toxin and streptolysin O [103-107]. A technique called suicide gene therapy could eventually employ pore forming toxins to deliver apoptotic agents directly into cancer cells [102].

Toxins can be used as therapies to kill malignant populations of cells when coupled to a targeting agent such as an antibody. The use of a toxin/antibody therapy has been labeled "conjugated drug 
delivery" where the antibody delivers the toxin directly to the target cell population, usually a malignant cancer cell [108]. Many of these conjugates using various bacterial-derived toxins and immunotoxins are already in clinical trials [108]. Echotoxins are effective at very low concentrations and are stable with changing $\mathrm{pH}[37,71]$, which may be desirable qualities when designing conjugated drug leads.

Pore-forming toxins are also useful in analytical applications, namely nano-pore sensor research [109]. In brief, this technique can be used to determine properties of molecules by interactions with the pore (which has a known size and conductance), as well as sequestering molecules based on their permeability through the pore [109].

Whereas actinoporins in general bind to sphingomyelin, echotoxins in particular preferentially bind to gangliosides. Gangliosides are key factors in tumor angiogenesis, with expression of different gangliosides promoting or inhibiting angiogenesis [110,111]. Gangliosides are released by tumor cells into the surrounding matrix to stimulate vascularization [110,111]. An increased spread of tumors, stimulated by gangliosides, has been demonstrated for multiple cancer types such as lymphoma, melanoma, and neuroblastoma [110,111]. Echotoxin, while possibly having some potential for therapeutic use, has not yet been evaluated for prevention of angiogenesis.

There is also potential for use as a biomarker, as seen by the precedent of actinoporins and the cholera B subunit [111-114]. Cholera toxin B subunit, which similarly to echotoxins binds to gangliosides, has been used with a dye conjugate as a marker to identify ganglioside "rafts" [111,114]. In Alzheimer's disease, ganglioside rafts play a role in the formation and accumulation of neurotoxin $A \beta$ protein fibrils [111,114]. Despite many different potential applications of echotoxins, none of them have been investigated as of yet.

\section{Future Suggestions on Understudied Families}

Very little is known about many families of predatory gastropods and there remain many which are not covered by this review. For example, there is no confirmed report of toxins in Mitridae. Unlike other species discussed in this review, Mitridae do not possess a venom gland or accessory salivary glands [115]. However, several observations suggest that these species are capable of producing valuable bioactive substances [114,115]. Some species within Buccinidae and Muricidae, discussed in other sections, are known to produce bioactive compounds in their hypobranchial gland. The Mitre hypobranchial gland has been noted to secrete a thick substance that oxidizes when exposed to air and turns purple; this secretion has an unknown function [115]. The Mitridae differ from other species in that they possess an epiproboscis in addition to the muscular proboscis found in other predatory gastropods and the salivary glands directly connect to this epiproboscis [116]. West described Mitridae specimen as using the epiproboscis to deliver salivary gland secretions to recalcitrant prey during feeding [116]. The diet of these species exclusively comprise of sipunculan marine worms [117]. Whereas several authors have speculated about the possibility of bioactive compounds from Mitridae, this possibility has never been explored $[115,116]$.

Family Coralliophilinae (superfamily Muricoidea) are well-known predators of coral and apparently unaffected by the neurotoxins produced by corals [15]. This family may also be a source of useful bioactive compounds. In addition, other carnivorous or parasitic gastropod families could also be fruitful for bioprospectors. Less-well-known carnivorous superfamilies within Littorinimorpha and Neogastropoda include Vanikoroidea (parasitic), Turbinelloidea, and Volutoidea [17].

\section{Conclusions}

The potential for the discovery of active compounds in the venom of marine gastropods with applications in medicine, cellular biology or biotechnology is high and prompt further investigations. Apart from Conidae species, promising leads isolated from marine gastropod species have largely been ignored. New advances in technology, e.g., proteomics and transcriptomics, can now be used by researchers to rapidly catalog the protein and peptides expressed in the venom and saliva of marine 
gastropods, which is fundamental to help discover the compounds responsible for biological activity. Some compounds from marine gastropod besides the Conidae have been characterized and have shown potential biological, biotechnological, and/or medical applications. This suggests that most marine gastropods are a relatively untapped resource for new therapeutic leads.

Acknowledgments: This work was supported by an Australian Research Council (ARC) Discovery Project (DP150103990). Christina I. Schroeder is an ARC Future Fellow (FT160100055) and David J. Craik is an ARC Australian Laureate fellow (FL150100146).

Author Contributions: Ashlin H. Turner wrote the manuscript; David J. Craik, Quentin Kaas, and Christina I. Schroeder provided critical reviews and revisions of the manuscript.

Conflicts of Interest: The authors declare no conflicts of interest.

\section{Appendix A}

Table A1. Sequences used to generate Figure 5, presented in the same order as shown in the figure. Accession numbers provided where applicable.

\begin{tabular}{ccc}
\hline Organism & Toxin & Accession Number \\
\hline Monoplex echo & Echotoxin 2 & Q76CA2 \\
Cinguloterebra anilis & Tereporin-Ca1 & P0DN66 \\
Conus geographus & Conoporin 5 & W4VS02 \\
Actinia fragacea & Delta-actitoxin-Afr1a & B9W5G6 \\
\hline
\end{tabular}

\section{References}

1. Akondi, K.B.; Muttenthaler, M.; Dutertre, S.; Kaas, Q.; Craik, D.J.; Lewis, R.J.; Alewood, P.F. Discovery, synthesis, and structure-activity relationships of conotoxins. Chem. Rev. 2014, 114, 5815-5847. [CrossRef] [PubMed]

2. Kaas, Q.; Craik, D.J. Conotoxins and other conopeptides. In Outstanding Marine Molecules: Chemistry, Biology, Analysis; Wiley-VCH Verlag GmbH and co.: Weinheim, Germany, 2014; Chapter 14; pp. 319-332.

3. West, D.J.; Andrews, E.B.; Bowman, D.; McVean, A.R.; Thorndyke, M.C. Toxins from some poisonous and venemous marine snails. Comp. Biochem. Physiol. 1996, 113, 1-10.

4. Duda, T.F., Jr.; Kohn, A.J.; Matheny, A.M. Cryptic species differentiated in Conus ebraeus, a widespread tropical marine gastropod. Biol. Bull. 2009, 217, 292-305. [CrossRef] [PubMed]

5. Rockel, D.; Korn, W.; Kohn, A.J. The Indo-Pacific Region; Verlag: Wiesbaden, Germany, 1995; Volume 1.

6. Terlau, H.; Olivera, B.M. Conus venoms: A rich source of novel ion channel-targeted peptides. Physiol. Rev. 2004, 84, 41-68. [CrossRef] [PubMed]

7. Davis, J.; Jones, A.; Lewis, R.J. Remarkable inter- and intra-species complexity of conotoxins revealed by LC/MS. Peptides 2009, 30, 1222-1227. [CrossRef] [PubMed]

8. Olivera, B.M. Conus venom peptides: Reflections from the biology of clades and species. Annu. Rev. Ecol. Syst. 2002, 33, 25-47. [CrossRef]

9. Olivera, B.M.; Cruz, L.J. Conotoxins, in retrospect. Toxicon 2001, 39, 7-14. [CrossRef]

10. Miljanich, G.P. Ziconotide: Neuronal calcium channel blocker for treating severe chronic pain. Curr. Med. Chem. 2004, 11, 3029-3040. [CrossRef] [PubMed]

11. Holford, M.; Puillandre, N.; Terryn, Y.; Cruaud, C.; Olivera, B.; Bouchet, P. Evolution of the toxoglossa venom apparatus as inferred by molecular phylogeny of the Terebridae. Mol. Biol. Evol. 2009, 26, 15-25. [CrossRef] [PubMed]

12. West, D.J.; Andrews, E.B.; McVean, A.R.; Osborne, D.J.; Thorndyke, M.C. Isolation of serotonin from the accessory glands of the marine snail Nucella lapillus. Toxicon 1994, 32, 1261-1264. [CrossRef]

13. Barkalova, V.O.; Fedosov, A.E.; Kantor, Y.I. Morphology of the anterior digestive system of Tonnoideans (gastropoda: Caenogastropoda) with an emphasis on the foregut glands. Molluscan Res. 2016, 36, 54-73. [CrossRef] 
14. Ponte, G.; Modica, M.V. Salivary glands in predatory mollusks: Evolutionary considerations. Front. Physiol 2017, 8, 580. [CrossRef] [PubMed]

15. Modica, M.V.; Holford, M. The neogastropoda: Evolutionary innovations of predatory marine snails with remarkable pharmacological potential. In Evolutionary Biology-Concepts, Molecular and Morphological; Pontarotti, P., Ed.; Springer: Berlin/Heidelberg, Germany, 2010.

16. Tucker, J. Catalog of recent and fossil Turrids (mollusca: Gastropoda). Zootaxa 2004, 682, 1-1295.

17. WoRMS. World Register of Marine Species. 2018. Available online: http://www.marinespecies.org/about. php (accessed on 1 November 2017).

18. Imperial, J.S.; Kantor, Y.; Watkins, M.; Heralde, F.M., 3rd; Stevenson, B.; Chen, P.; Hansson, K.; Stenflo, J.; Ownby, J.P.; Bouchet, P.; et al. Venomous auger snail Hastula (Impages) hectica (linnaeus, 1758): Molecular phylogeny, foregut anatomy and comparative toxinology. J. Exp. Zool. B Mol. Dev. Evol. 2007, 308, 744-756. [CrossRef] [PubMed]

19. Puillandre, N.; Holford, M. The terebridae and teretoxins: Combining phylogeny and anatomy for concerted discovery of bioactive compounds. BMC Chem. Biol. 2010, 10, 7. [CrossRef] [PubMed]

20. Heralde, F.M., 3rd; Imperial, J.; Bandyopadhyay, P.K.; Olivera, B.M.; Concepcion, G.P.; Santos, A.D. A rapidly diverging superfamily of peptide toxins in venomous Gemmula species. Toxicon 2008, 51, 890-897. [CrossRef] [PubMed]

21. Gorson, J.; Ramrattan, G.; Verdes, A.; Wright, E.M.; Kantor, Y.; Rajaram Srinivasan, R.; Musunuri, R.; Packer, D.; Albano, G.; Qiu, W.G.; et al. Molecular diversity and gene evolution of the venom arsenal of Terebridae predatory marine snails. Genome Biol. Evol. 2015, 7, 1761-1778. [CrossRef] [PubMed]

22. Imperial, J.S.; Watkins, M.; Chen, P.; Hillyard, D.R.; Cruz, L.J.; Olivera, B.M. The augertoxins: Biochemical characterization of venom components from the toxoglossate gastropod Terebra subulata. Toxicon 2003, 42, 391-398. [CrossRef]

23. Kaas, Q.; Westermann, J.C.; Craik, D.J. Conopeptide characterization and classifications: An analysis using conoserver. Toxicon 2010, 55, 1491-1509. [CrossRef] [PubMed]

24. Czerwiec, E.; Kalume, D.E.; Roepstorff, P.; Hambe, B.; Furie, B.; Furie, B.C.; Stenflo, J. Novel gamma-carboxyglutamic acid-containing peptides from the venom of Conus textile. FEBS J. 2006, 273, 2779-2788. [CrossRef] [PubMed]

25. Zugasti-Cruz, A.; Aguilar, M.B.; Falcon, A.; Olivera, B.M.; Heimer de la Cotera, E.P. Two new 4-Cys conotoxins (framework 14) of the vermivorous snail Conus austini from the Gulf of Mexico with activity in the central nervous system of mice. Peptides 2008, 29, 179-185. [CrossRef] [PubMed]

26. Anand, P.; Grigoryan, A.; Bhuiyan, M.H.; Ueberheide, B.; Russell, V.; Quinonez, J.; Moy, P.; Chait, B.T.; Poget, S.F.; Holford, M. Sample limited characterization of a novel disulfide-rich venom peptide toxin from terebrid marine snail Terebra variegata. PLoS ONE 2014, 9, e94122. [CrossRef] [PubMed]

27. Moon, J.; Gorson, J.; Wright, M.E.; Yee, L.; Khawaja, S.; Shin, H.Y.; Karma, Y.; Musunri, R.L.; Yun, M.; Holford, M. Characterization and recombinant expression of terebrid venom peptide from Terebra guttata. Toxins (Basel) 2016, 8, 63. [CrossRef] [PubMed]

28. Kendel, Y.; Melaun, C.; Kurz, A.; Nicke, A.; Peigneur, S.; Tytgat, J.; Wunder, C.; Mebs, D.; Kauferstein, S. Venomous secretions from marine snails of the Terebridae family target acetylcholine receptors. Toxins (Basel) 2013, 5, 1043-1050. [CrossRef] [PubMed]

29. Bouchet, P.; Kantor, Y.I.; Sysoev, A.; Puillandre, N. A new operational classification of the Conoidea (gastropoda). J. Moll. Stud. 2011, 46, 273-308. [CrossRef]

30. Bouchet, P.; Waren, A. Revision of the Northeast Atlantic bathyal and abyssal Turridae (mollusca, gastropoda). J. Moll. Stud. 1980, 46, 1-119. [CrossRef]

31. Lopez-Vera, E.; Heimer de la Cotera, E.P.; Maillo, M.; Riesgo-Escovar, J.R.; Olivera, B.M.; Aguilar, M.B. A novel structural class of toxins: The methionine-rich peptides from the venoms of Turrid marine snails (mollusca, conoidea). Toxicon 2004, 43, 365-374. [CrossRef] [PubMed]

32. Watkins, M.; Hillyard, D.R.; Olivera, B.M. Genes expressed in a Turrid venom duct: Divergence and similarity to conotoxins. J. Mol. Evol. 2006, 62, 247-256. [CrossRef] [PubMed]

33. Omaga, C.A.; Carpio, L.D.; Imperial, J.S.; Daly, N.L.; Gajewiak, J.; Flores, M.S.; Espino, S.S.; Christensen, S.; Filchakova, O.M.; Lopez-Vera, E.; et al. Structure and biological activity of a turripeptide from Unedogemmula bisaya venom. Biochemistry 2017, 56, 6051-6060. [CrossRef] [PubMed] 
34. Emmelin, N.; Fange, R. Comparison between biological effects of neurine and a salivary gland extract of Neptunea antiqua. Acta Zool. 1958, 39, 47-52. [CrossRef]

35. Fange, R. Venoms and venom glands of marine molluscs. In Toxins, Drugs, and Pollutants in Marine Animals; Bolis, L., Zadunaisky, J., Gilles, R., Eds.; Springer-Verlag: Berlin, Germany, 1984; pp. 47-62.

36. Shiomi, K.; Mizukami, M.; Shimakura, K.; Nagashima, Y. Toxins in the salivary gland of some marine carnivorous gastropods Comp. Biochem. Physiol. 1994, 107B, 427-432.

37. Shiomi, K.; Kawashima, Y.; Mizukami, M.; Nagashima, Y. Properties of proteinaceous toxins in the salivary gland of the marine gastropod (Monoplex echo). Toxicon 2002, 40, 563-571. [CrossRef]

38. Day, J.A. Feeding of the cymatiid gastropod, Argobuccinum argus, in relation to the structure of the proboscis and secretions of the proboscis gland. Am. Zool. 1969, 9, 909-916. [CrossRef]

39. Anthoni, U.; Bohlin, L.; Larsen, C.; Nielsen, P.; Nielsen, N.H.; Christophersen, C. Tetramine: Occurrence in marine organisms and pharmacology. Toxicon 1989, 27, 707-716. [CrossRef]

40. Asano, M.; Ito, M. Occurrence of tetramine and choline compounds in the salivary gland of a marine gastropod Neptunea arthritica, Bernardi. Tohuku J. Agric. Res. 1959, 10, $209-227$.

41. Anthoni, U.; Bohlin, L.; Larsen, C.; Nielsen, P.; Nielsen, N.H.; Christophersen, C. The toxin tetramine from the "edible" whelk Neptunea antiqua. Toxicon 1989, 27, 717-723. [CrossRef]

42. Reid, T.M.; Gould, I.M.; Mackie, I.M.; Ritchie, A.H.; Hobbs, G. Food poisoning due to the consumption of red whelks (Neptunea antiqua). Epidemiol. Infect. 1988, 101, 419-423. [CrossRef] [PubMed]

43. Welsh, J.H. Composition and mode of action of some invertebrate venoms. Annu. Rev. Pharmacol. 1964, 4, 293-304. [CrossRef]

44. Sarumathi, G.; Arumugam, M.; Kumaresan, S.; Balasubramanian, T. Studies on bioprospecting potential of a gastropod mollusc Cantharus tranquebaricus (Gmelin, 1791). Asian Pac. J. Trop. Biomed. 2012, 2, 759-764. [CrossRef]

45. Endean, R. Aspects of Molluscan Pharmacology; Academic Press: New York, NY, USA, 1972; Volume 7.

46. Himmelman, J.H.; Hamel, J.R. Diet, behavior, and reproduction of the whelk Buccinum undatum in the northern gulf of st. Lawrence, eastern canada. Mar. Biol. 1993, 116, 423-430. [CrossRef]

47. Cornman, I. Toxic properties of the saliva of Cassis. Nature 1963, 200, 88-89. [CrossRef]

48. Modica, M.V.; Lombardo, F.; Franchini, P.; Oliverio, M. The venomous cocktail of the vampire snail Colubraria reticulata (mollusca, gastropoda). BMC Genom. 2015, 16, 441. [CrossRef] [PubMed]

49. Voultsiadou, E. Therapeutic properties and uses of marine invertebrates in the ancient Greek world and early Byzantium. J. Ethnopharmacol. 2010, 130, 237-247. [CrossRef] [PubMed]

50. Benkendorff, K.; Rudd, D.; Nongmaithem, B.D.; Liu, L.; Young, F.; Edwards, V.; Avila, C.; Abbott, C.A. Are the traditional medical uses of muricidae mulluscs substantiated by their pharmacological properties and bioactive compounds? Mar. Drugs 2015, 13, 5237-5275. [CrossRef] [PubMed]

51. Benkendorff, K.; McIver, C.; Abbott, C. Bioactivity of the murex homeopathic remedy and of extracts from an Australian muricid mollusc against human cancer cells. J. Evid. Based Complement. Altern. Med. 2009, 2011, 1-12.

52. Vine, K.L.; Locke, J.M.; Ranson, M.; Benkendorff, K.; Pyne, S.G.; Bremner, J.B. In vitro cytotoxicity evaluation of some substituted isatin derivatives. Bioorg. Med. Chem. 2007, 15, 931-938. [CrossRef] [PubMed]

53. Edwards, V.; Benkendorff, K.; Young, F. Marine compounds selectively induce apoptosis in female reproductive cancer cells but not in primary-derived human reproductive granulosa cells. Mar. Drugs 2012, 10, 64-83. [CrossRef] [PubMed]

54. Benkendorff, K. Natural product research in the Australian marine invertebrate Dicathais orbita. Mar. Drugs 2013, 11, 1370-1398. [CrossRef] [PubMed]

55. Roseghini, M.; Severini, C.; Erspamer, G.F.; Erspamer, V. Choline esters and biogenic amines in the hypobranchial gland of 55 molluscan species of the neogastropod muricoidea superfamily. Toxicon 1996, 34, 33-55. [CrossRef]

56. Andrews, E.B.; Elphick, M.R.; Thorndyke, M. Pharmacologically active constituents of the accessory salivary and hypobranchial glands of Nucella lapillus. J. Moll. Stud. 1991, 57, 136-138. [CrossRef]

57. Andrews, E.B. The fine structure and function of the salivary glands of Nucella lapillus (gastropoda: Muricidae). J. Moll. Stud. 1991, 57, 111-126. [CrossRef]

58. Andrews, E.B.; Page, A.M.; Taylor, J.D. The fine structure and function of the anterior foregut glands of Cymatium intermedius (cassoidea: Ranellidae). J. Moll. Stud. 1999, 65, 1-19. [CrossRef] 
59. Hemingway, G.T. Evidence for a paralytic venom in the intertidal snail, Acanthina spirata (neogastropoda: Thaisidae). Comp. Biochem. Physiol. 1977, 60, 78-81. [CrossRef]

60. Huang, C.L.; Mir, G.N. Pharmacological properties of hypobranchial gland of Thais haemastoma (clench). J. Pharm. Sci. 1971, 60, 1842-1846. [CrossRef] [PubMed]

61. Morton, B. Foregut anatomy and predation by Charonia lampas (gastropoda: Prosobranchia: Neotaenioglossa) attacking Ophidiaster ophidianus (asteroidea: Ophidiasteridae) in the azores, with a review of triton feeding behavior. J. Nat. Hist. 2012, 46, 2621-2637. [CrossRef]

62. Chau, R.; Kalaitzis, J.A.; Neilan, B.A. On the origins and biosynthesis of tetrodotoxin. Aquat. Toxicol. 2011, 104, 61-72. [CrossRef] [PubMed]

63. Bose, U.; Wang, T.; Zhao, M.; Motti, C.A.; Hall, M.R.; Cummins, S.F. Multiomics analysis of the giant triton snail salivary gland, a crown-of-thorns starfish predator. Sci. Rep. 2017, 7, 6000. [CrossRef] [PubMed]

64. Edgar, R.C. Muscle: A multiple sequence alignment method with reduced time and space complexity. BMC Bioinf. 2004, 5, 113. [CrossRef] [PubMed]

65. Berg, J.M.; Tymoczko, J.L.; Stryer, L. Biochemistry; Freeman, W.H.: New York, NY, USA, 2002.

66. Guimaraes, D.O.; Lopes, D.S.; Azevedo, F.V.; Gimenes, S.N.; Silva, M.A.; Ache, D.C.; Gomes, M.S.; Vecchi, L.; Goulart, L.R.; Yoneyama, K.A.; et al. In Vitro antitumor and antiangiogenic effects of bothropoidin, a metalloproteinase from Bothrops pauloensis snake venom. Int. J. Biol. Macromol. 2017, 97, 770-777. [CrossRef] [PubMed]

67. Warren, W.C.; Hillier, L.W.; Marshall Graves, J.A.; Birney, E.; Ponting, C.P.; Grutzner, F.; Belov, K.; Miller, W.; Clarke, L.; Chinwalla, A.T.; et al. Genome analysis of the platypus reveals unique signatures of evolution. Nature 2008, 453, 175-183. [CrossRef] [PubMed]

68. Bose, U.; Suwansa-Ard, S.; Maikaeo, L.; Motti, C.A.; Hall, M.R.; Cummins, S.F. Neuropeptides encoded within a neural transcriptome of the giant triton snail Charonia tritonis, a crown-of-thorns starfish predator. Peptides 2017, 98, 3-14. [CrossRef] [PubMed]

69. Cruz, L.J.; de Santos, V.; Zafaralla, G.C.; Ramilo, C.A.; Zeikus, R.; Gray, W.R.; Olivera, B.M. Invertebrate vasopressin/oxytocin homologs. Characterization of peptides from Conus geographus and Conus straitus venoms. J. Biol. Chem. 1987, 262, 15821-15824. [PubMed]

70. van Soest, P.F.; Kits, K.S. Conopressin affects excitability, firing, and action potential shape through stimulation of transient and persistent inward currents in mulluscan neurons. J. Neurophysiol. 1998, 79, 1619-1632. [CrossRef] [PubMed]

71. Kawashima, Y.; Nagai, H.; Ishida, M.; Nagashima, Y.; Shiomi, K. Primary structure of echotoxin 2, an actinoporin-like hemolytic toxin from the salivary gland of the marine gastropod Monoplex echo. Toxicon 2003, 42, 491-497. [CrossRef]

72. West, D.J.; Andrews, E.B.; McVean, A.R.; Thorndyke, M.C.; Taylor, J.D. Presence of a toxin in the salivary glands of the marine snail Cymatium intermedius that targets nicotinic acetylcholine receptors. Toxicon 1998, 36, 25-29. [CrossRef]

73. Bellomio, A.; Morante, K.; Barlic, A.; Gutierrez-Aguirre, I.; Viguera, A.R.; Gonzalez-Manas, J.M. Purification, cloning and characterization of fragaceatoxin $\mathrm{C}$, a novel actinoporin from the sea anemone Actinia fragacea. Toxicon 2009, 54, 869-880. [CrossRef] [PubMed]

74. Anderluh, G.; Macek, P. Cytolytic peptide and protein toxins from sea anemones (anthozoa: Actiniaria). Toxicon 2002, 40, 111-124. [CrossRef]

75. Violette, A.; Biass, D.; Dutertre, S.; Koua, D.; Piquemal, D.; Pierrat, F.; Stocklin, R.; Favreau, P. Large-scale discovery of conopeptides and conoproteins in the injectable venom of a fish-hunting cone snail using a combined proteomic and transcriptomic approach. J. Proteom. 2012, 75, 5215-5225. [CrossRef] [PubMed]

76. Luo, X.; Yu, R.C.; Wang, X.J.; Zhou, M.J. Toxin composition and toxicity dynamics of marine gastropod Nassarius spp. Collected from lianyungang, china. Food Addit. Contam. Part A Chem. Anal. Control Expo. Risk Assess. 2012, 29, 117-127. [CrossRef] [PubMed]

77. Wang, X.J.; Yu, R.C.; Luo, X.; Zhou, M.J.; Lin, X.T. Toxin-screening and identification of bacteria isolated from highly toxic marine gastropod Nassarius semiplicatus. Toxicon 2008, 52, 55-61. [CrossRef] [PubMed]

78. Costa, P.R.; Costa, S.T.; Braga, A.C.; Rodrigues, S.M.; Vale, P. Relevance and challenges in monitoring marine biotoxins in non-bivalve vectors. Food Control 2017, 76, 24-33. [CrossRef] 
79. Borysko, L.; Ross, P.M. Adult exposure to the synthetic hormone 17alpha-ethynylestradiol affects offspring of the gastropods Nassarius burchardi and Nassarius jonasii. Ecotoxicol. Environ. Saf. 2014, 103, 91-100. [CrossRef] [PubMed]

80. Choi, M.C.; Yu, P.K.; Hsieh, D.P.; Lam, P.K. Trophic transfer of paralytic shellfish toxins from clams (Ruditapes philippinarum) to gastropods (Nassarius festivus). Chemosphere 2006, 64, 1642-1649. [CrossRef] [PubMed]

81. Coelho, J.P.; Pimenta, J.; Gomes, R.; Barroso, C.M.; Pereira, M.E.; Pardal, M.A.; Duarte, A. Can Nassarius reticulatus be used as a bioindicator for $\mathrm{Hg}$ contamination? Results from a longitudinal study of the Portuguese coastline. Mar. Pollut. Bull. 2006, 52, 674-680. [CrossRef] [PubMed]

82. Hwang, P.A.; Tsai, Y.H.; Deng, J.F.; Cheng, C.A.; Ho, P.H.; Hwang, D.F. Identification of tetrodotoxin in a marine gastropod (Nassarius glans) responsible for human morbidity and mortality in Taiwan. J. Food Prot. 2005, 68, 1696-1701. [CrossRef] [PubMed]

83. Zou, S.; Li, Q.; Kong, L. Monophyly, distance and character-based multigene barcoding reveal extraordinary cryptic diversity in Nassarius: A complex and dangerous community. PLoS ONE 2012, 7, e47276. [CrossRef] [PubMed]

84. Minniti, F. Morphological and histochemical study of pharynx of Leiblein, salivary glands, and gland of Leiblein in the carnivorous gastropoda Amyclina tinei maravigna and Cyclope neritea larnarck (nassariidae: Prosobranchia stenoglossa). Zool. Anz. 1986, 217, 14-22.

85. Huang, H.N.; Lin, J.; Lin, H.L. Identification and quantification of tetrodotoxin in the marine gastropod Nassarius by LC-MS. Toxicon 2008, 51, 774-779. [CrossRef] [PubMed]

86. Galindo, L.A.; Puillandre, N.; Utge, J.; Lozouet, P.; Bouchet, P. The phylogeny and systematics of the Nassariidae revisited (gastropoda, buccinoidea). Mol. Phylogenet. Evol. 2016, 99, 337-353. [CrossRef] [PubMed]

87. Neidleman, S.L.; Laskin, A.I. Advances in Applied Microbiology; Academic Press: Cambridge, MA, USA, 1997; Chapter 2; Volume 43.

88. Teichert, R.W.; Olivera, B.M. Natural products and ion channel pharmacology. Future Med. Chem. 2010, 2, 731-744. [CrossRef] [PubMed]

89. Williams, A.J.; Dave, J.R.; Phillips, J.B.; Lin, Y.; McCabe, R.T.; Tortella, F.C. Neuroprotective efficacy and therapeutic window of the high-affinity $N$-methyl-D-aspartate antagonist conantokin-G: In vitro (primary cerebellar neurons) and in vivo (rat model of transient focal brain ischemia) studies. J. Pharmacol. Exp. Ther. 2000, 294, 378-386. [PubMed]

90. Balsara, R.; Dang, A.; Donahue, D.L.; Snow, T.; Castellino, F.J. Conantokin-g attenuates detrimental effects of nmdar hyperactivity in an ischemic rat model of stroke. PLoS ONE 2015, 10, e0122840. [CrossRef] [PubMed]

91. Halai, R.; Craik, D.J. Conotoxins: Natural product drug leads. Nat. Prod. Rep. 2009, 26, 526-536. [CrossRef] [PubMed]

92. Benkendorff, K.; Bremner, J.B.; Davis, A.R. Tyrian purple precursors in the egg masses of the Australian muricid, Dicathais orbita: A possible defensive role. J. Chem. Ecol. 2000, 26, 1037-1050. [CrossRef]

93. Esmaeelian, B. Preclinical In Vitro and In Vivo Effects of Purified and Synthetic Bioactive Compounds from Marine Mollusc Dicathais orbita on Colorectal Cancer: Cancer Prevention and Toxicity Study; Flinders University: Adelaide, Australia, 2013.

94. Esmaeelian, B.; Abbott, C.A.; Le Leu, R.K.; Benkendorff, K. 6-bromoisatin found in muricid mollusc extracts inhibits colon cancer cell proliferation and induces apoptosis, preventing early stage tumor formation in a colorectal cancer rodent model. Mar. Drugs 2014, 12, 17-35. [CrossRef] [PubMed]

95. Esmaeelian, B.; Benkendorff, K.; Le Leu, R.K.; Abbott, C.A. Simultaneous assessment of the efficacy and toxicity of marine mollusc-derived brominated indoles in an in vivo model for early stage colon cancer. Integr. Cancer Ther. 2017, 1534735417699880. [CrossRef] [PubMed]

96. Kim, J.K.; Park, G.M. Indirubin-3-monoxime exhibits anti-inflammatory properties by down-regulating Nf-kappab and JNK signaling pathways in lipopolysaccharide-treated RAW264.7 cells. Inflamm. Res. 2012, 61, 319-325. [CrossRef] [PubMed]

97. Ahmad, T.B.; Rudd, D.; Smith, J.; Kotiw, M.; Mouatt, P.; Seymour, L.M.; Liu, L.; Benkendorff, K. Anti-inflammatory activity and structure-activity relationships of brominated indoles from a marine mollusc. Mar. Drugs 2017, 15, 133. [CrossRef] [PubMed] 
98. Ahmad, T.B.; Rudd, D.; Benkendorff, K.; Mahdi, L.K.; Pratt, K.A.; Dooley, L.; Wei, C.; Kotiw, M. Brominated indoles from a marine mollusc inhibit inflammation in a murine model of acute lung injury. PLoS ONE 2017, 12, e0186904. [CrossRef] [PubMed]

99. Stevens, R.W.; Morita, H.; Nakane, N. Indole Derivatives as Antiallergy and Antiinflammatory Agents. U.S. Patent US 5290788A, 1 March 1994.

100. Erspamer, V.; Glasser, A. The pharmacological actions of murexine (urocanylcholine). Br. J. Pharmacol. Chemother. 1957, 12, 176-184. [CrossRef] [PubMed]

101. Erspamer, V.; Glasser, A. The pharmacological actions of some murexine-like substances. Br. J. Pharmacol. Chemother. 1958, 13, 378-384. [CrossRef] [PubMed]

102. Peraro, M.D.; van der Goot, F.G. Pore-forming toxins: Ancient, but never really out of fashion. Nat. Rev. 2016, 14, 77-92. [CrossRef] [PubMed]

103. Dyer, P.D.R.; Shepherd, T.R.; Gollings, A.S.; Shorter, S.A.; Gorringe-Pattrick, M.A.M.; Tang, C.K.; Cattoz, B.N.; Baillie, L.; Griffiths, P.C.; Richardson, S.C.W. Disarmed anthrax toxin delivers antisense oligonucleotides and sirna with high efficiency and low toxicity. J. Control Release 2015, 220, 316-328. [CrossRef] [PubMed]

104. Barbier, J.; Gillet, D. Engineering of Bacterial Toxins for Research and Medicine. In The Comprehensive Sourcebook of Bacterial Protein Toxins; Institute of Biology and Technology of Saclay: Gif sur Yvette, France, 2015; Chapter 35.

105. Liao, X.; Rabideau, A.E.; Pentelute, B.L. Delivery of antibody mimics into mammalian cells via anthrax toxin protective antigen. ChemBioChem 2014, 15, 2458-2466. [CrossRef] [PubMed]

106. Rabideau, A.E.; Pentelute, B.L. Delivery of non-native cargo into mammalian cells using anthrax lethal toxin. ACS Chem. Biol. 2016, 11, 1490-1501. [CrossRef] [PubMed]

107. Verdermen, W.; Luginbuhl, M.; Honegger, A.; Pluckthum, A. Effecient cell-specific uptake of binding proteins into the cytoplasm through engineered modular transport systems. J. Control. Release 2015, 200, 13-22. [CrossRef] [PubMed]

108. Dosio, F.; Stella, B.; Cerioni, S.; Gastaldi, D.; Arpicco, S. Advances in anticancer antibody-drug conjugates and immunotoxins. Recent Pat. Anticancer Drug Discov. 2014, 9, 35-65. [CrossRef] [PubMed]

109. Kasianowicz, J.J.; Balijepalli, A.K.; Ettedgui, J.; Forstater, J.H.; Wang, H.; Zhang, H.; Robertson, J.W. Analytical applications for pore-forming proteins. Biochim. Biophys. Acta 2016, 1858, 593-606. [CrossRef] [PubMed]

110. Mukherjee, P.; Faber, A.C.; Shelton, L.M.; Baek, R.C.; Chiles, T.C.; Seyfried, T.N. Thematic review series: Sphingolipids. Ganglioside GM3 suppresses the proangiogenic effects of vascular endothelial growth factor and ganglioside GD1A. J. Lipid Res. 2008, 49, 929-938. [CrossRef] [PubMed]

111. Yu, R.K.; Tsai, Y.T.; Ariga, T.; Yanagisawa, M. Structures, biosynthesis, and functions of gangliosides-An overview. J. Oleo Sci. 2011, 60, 537-544. [CrossRef] [PubMed]

112. Lorizate, M.; Brugger, B.; Akiyama, H.; Glass, B.; Muller, B.; Anderluh, G.; Wieland, F.T.; Krausslich, H.G. Probing HIV-1 membrane liquid order by laurdan staining reveals producer cell-dependent differences. J. Biol. Chem. 2009, 284, 22238-22247. [CrossRef] [PubMed]

113. Yamaji-Hasegawa, A.; Hullin-Matsuda, F.; Greimel, P.; Kobayashi, T. Pore-forming toxins: Properties, diversity, and uses as tools to image sphingomyelin and ceramide phosphoethanolamine. Biochim. Biophys. Acta 2016, 1858, 576-592. [CrossRef] [PubMed]

114. Matsuzaki, K.; Kato, K.; Yanagisawa, K. Abeta polymerization through interaction with membrane gangliosides. Biochim. Biophys. Acta 2010, 1801, 868-877. [CrossRef] [PubMed]

115. Harasewych, M.G. Anatomy and biology of Mitra cornea lamarck, 1811 (mollusca, caenogastropoda, mitridae) from the azores. Acoreana 2009, 6, 121-135.

116. West, T.L. Feeding behavior and functional morphology of the epiproboscis of Mitra idae. Bull. Mar. Sci. 1990, $46,761-779$.

117. Taylor, J.D. The diet of coral-reef Mitridae (gastropoda) from guam; with a review of other species of the family. J. Nat. Hist. 1989, 23, 261-278. [CrossRef]

(C) 2018 by the authors. Licensee MDPI, Basel, Switzerland. This article is an open access article distributed under the terms and conditions of the Creative Commons Attribution (CC BY) license (http:/ / creativecommons.org/licenses/by/4.0/). 